\title{
Climbers from two rock outcrops in the semi-arid region of Brazil
}

\author{
Danielly da Silva Lucena, ${ }^{1}$ Maria de Fátima de A. Lucena, ${ }^{2}$ Marccus Alves ${ }^{1}$
}

1 Universidade Federal de Pernambuco, Centro de Ciências Biológicas, Laboratório de Morfo-taxonomia vegetal, Av. Prof. Moraes Rêgo, s/n, Cidade Universitária. 50670-901, Recife., PE, Brazil. 2 Universidade Federal de Campina Grande, Centro de Saúde e Tecnologia Rural, Av. Universitária, s/n, Santa Cecília, CEP 58708-110, Patos, PB, Brazil.

Corresponding author: Danielly da Silva Lucena, botanicadane@gmail.com

\begin{abstract}
This study aimed to recognize the floristic composition, the life form and the distribution of species of climbing plants occurring on 2 rock outcrops in the state of Pernambuco. Monthly botanical collections were made from February to September 2015 at Pedra do Cruzeiro $\left(08^{\circ} 09^{\prime} 02.9^{\prime \prime}\right.$ S, $035^{\circ} 45^{\prime} 22.3^{\prime \prime}$ W), municipality of Bezerros and Pico do Papagaio $\left(07^{\circ} 49^{\prime} 25.7^{\prime \prime} \mathrm{S}, 038^{\circ} 03^{\prime} 14.8^{\prime \prime} \mathrm{W}\right)$, municipality of Triunfo. Fertile specimens were collected following the standard methodology in taxonomy. A total of 58 species were identified from the 2 areas, all widely distributed in Brazil and belonging to 20 botanical families. Apocynaceae, Convolvulaceae, Bignoniaceae, Dioscoreaceae and Fabaceae comprise $60 \%$ of all species. The predominant life form was phanerophyte $(62 \%)$. As for the growth form, $67 \%$ of the climbers are herbaceous vines. The adaptation of twining was observed in $69 \%$ of species. Six new records for the state of Pernambuco were also identified. The rock outcrops studied show high species richness in relation to the found for climbers in other rock outcrops in the Brazilian Northeast Region.
\end{abstract}

\section{Key words}

Caatinga; flora; Neotropics; plant diversity; seasonal dry forest; vines.

Academic editor: Alexander Zizka | Received 20 June 2016 | Accepted 6 June 2017 | Published 11 September 2017

Citation: Lucena DS, Lucena MFA, Alves M (2017) Climbers from two rock outcrops in the semi-arid region of Brazil. Check List 13 (5): $417-427$. https://doi.org/10.15560/13.5.417

\section{Introduction}

Inselbergs and crystalline rock outcrops, are defined as mountainous islands or residual relief, which occur throughout all major climatic and vegetational zones but are particularly abundant in tropical regions (Jatobá and Lins 2003, Porembski 2007). In Brazil, they are common in the Caatinga Domain (Ab'Sáber 2003) and along the Atlantic coast in the Brazilian South and Southeast regions (Porembski 2007). The term "inselberg" has been mistakenly used as a synonym for "rock outcrop", but it refers exclusively to outcrops with a granite-gneiss composition and originating through the process of pediplanation (Morais 1983, Jatobá and Lins 2003).

Rock outcrops, including inselbergs, present peculiar ecological conditions where the vegetation grows on rock and differs from that occurring in the surrounding environment both in floristic and physiognomic aspects (Porto et al. 2008). This peculiarity is related mainly to the water shortage, lack of nutrients, intense solar radiation and elevated temperatures found in these ecosystems (Fabricante et al. 2010). Consequently, rock outcrops are considered places for speciation leading to a high number of endemic species (Safford and Martinelli 2000, Martinelli 2007, Gomes and Alves 2010, Porembski 2007). 

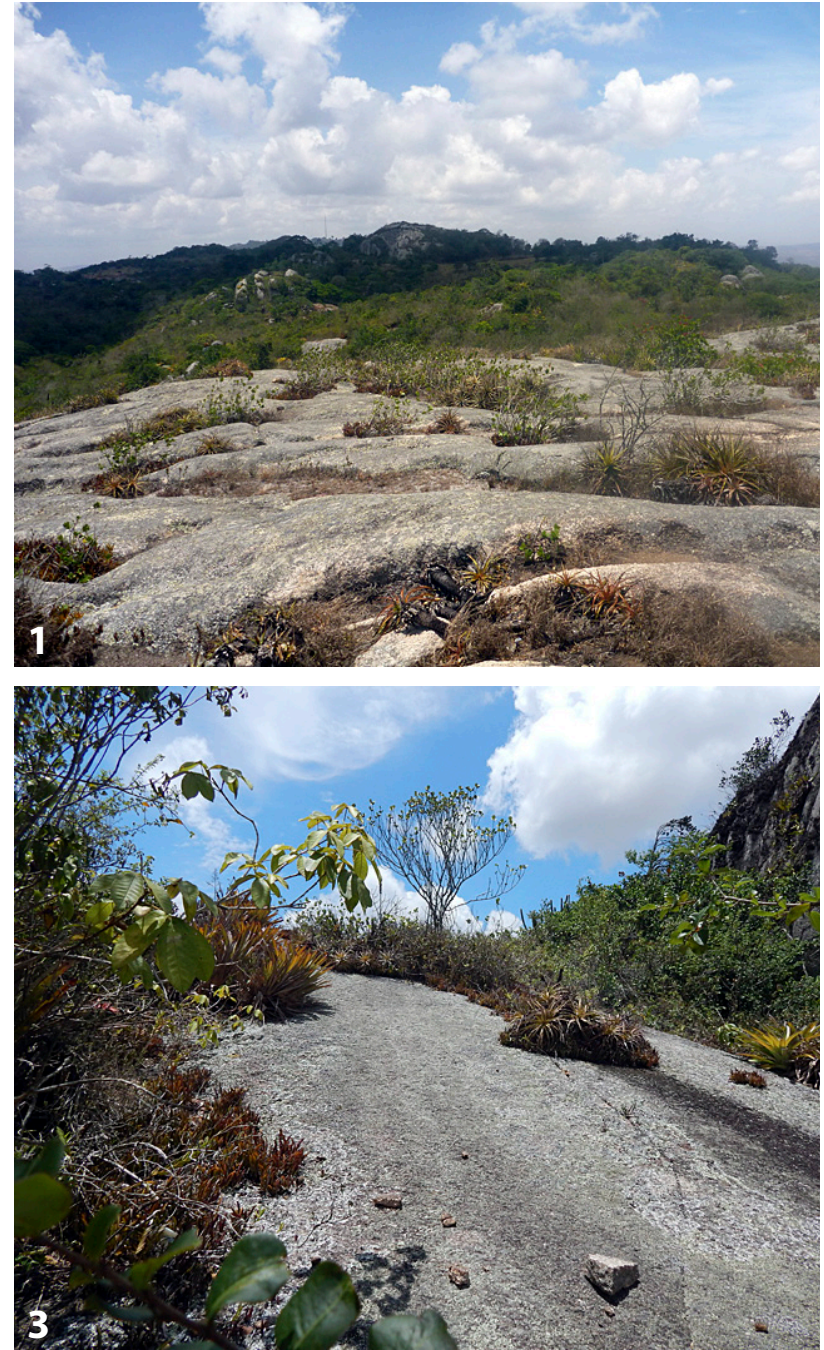
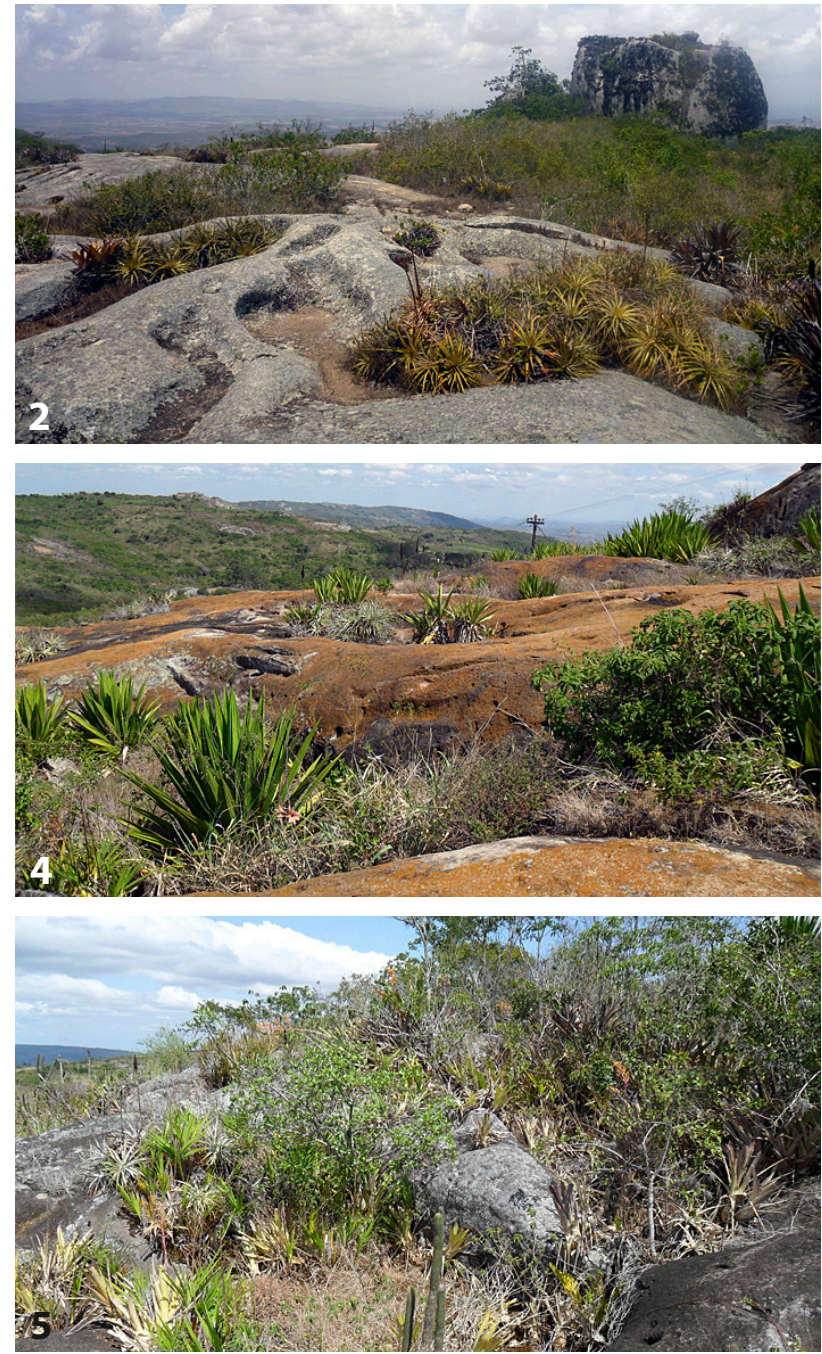

Figures 1-5. General appearance of the 2 rock outcrops studied. 1-3. Pedra do Cruzeiro (PC). 4, 5. Pico do Papagaio (PP). (Photos by J.R Maciel).

Climatic factors are the main modulators in the distribution of life forms in different environments (Raunkiaer 1934). Phanerophytes and hemicryptophytes are the most representative life forms on the rocky outcrops, these proportions may be related to the formation and deepness of the soil and water availability in these environments (França et al. 2005, 2006, Araújo et al. 2008, Gomes and Alves 2010). Therophytes, are also common and are usually recorded in areas with water stress, where the favorable season is short or unpredictable (Cain 1950), such as rock outcrops.

Vegetation on rock outcrops is discontinuous and, in sections with depressions where soils are deep enough, forms vegetation islands separated by exposed rock (Safford and Martinelli 2000, Martinelli 2007, Porembski 2007, Gomes and Alves 2009). These environments comprise the most diverse life forms and plant habits including climbing plants, which in turn, are an important element of the composition of tropical ecosystems (Darwin 1867, Putz 1984, Gentry 1991) and stand out in species richness in floristic surveys of rock outcrops in the Brazilian Northeast (Porto et al. 2008, Gomes and Alves 2009, Gomes et al. 2011, Tolke et al. 2011).
According to Weiser (2007), plants that have a climbing habit are autotrophic, vascular, germinate in the soil and maintain contact with the ground throughout their life cycle. Fordjour et al. (2008), point out the preference of climbing plants for younger forests due to the availability of smaller-diameter supports. According to Gentry (1991) and Barros et al. (2009), the abundance of these plants is associated with forest edges, stream banks, clearings and areas under anthropogenic influence.

There are few works of a floristic nature in Brazil that deal exclusively with climbing plants, of which many were conducted in the Brazilian Southeast (Weiser 2001, Hora and Soares 2002, Brandes 2007, Hora et al. 2008, Barros et al. 2009, Villagra and Romaniuc Neto 2010, Vargas et al. 2013). Information on climbing plants for the Brazilian Northeast is scarce and mostly restricted to floristic inventories and taxonomic studies. Studies with climbing plants in the region include Araújo and Alves (2010), García-González (2011) and Oliveira et al. (2012) for the Atlantic Domain, and Delgado Junior (2014) and Oliveira et al. (2015) for the Caatinga. Recently, Araújo (2014) compiled the data available in local collections at the Northeast region and presented a list of 468 climbing 


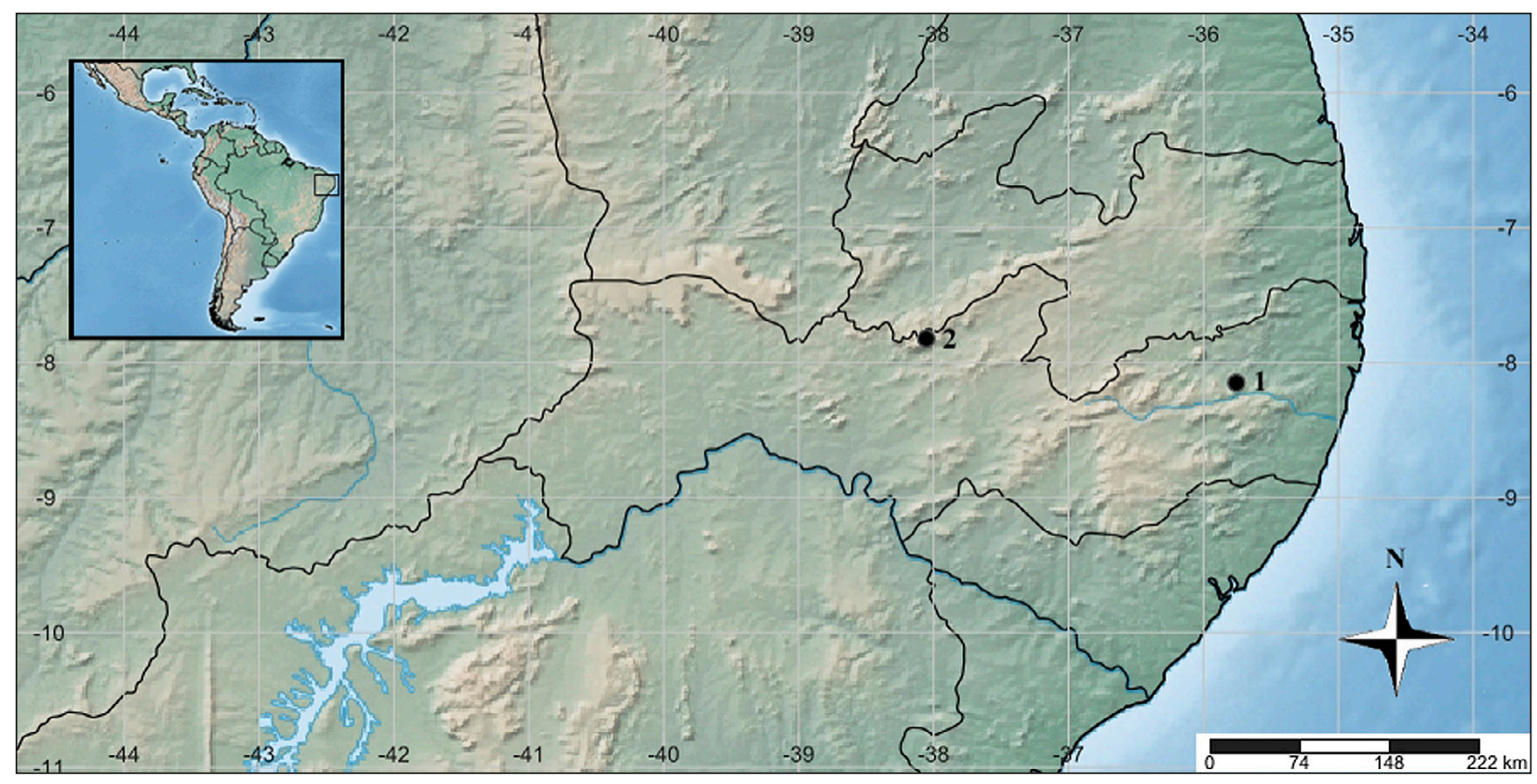

Figure 6. Map with the location of the study area. Legend - 1: Pedra do Cruzeiro, 2: Pico do Papagaio.

species found in the Caatinga. There is no floristic study focusing on the taxonomic richness and distribution of climbing species on the rock outcrops of Brazil.

Given the above, this study aimed to recognize the floristic composition, the life form and the distribution of climbing plants species occurring on 2 rock outcrops in the state of Pernambuco, thereby contributing to a better floristic characterization of these environments in the Brazilian Northeast.

\section{Methods}

Study site. This study was conducted on 2 rock outcrops, Pedra do Cruzeiro and Pico do Papagaio, in the state of Pernambuco, located in the muncipalites of Bezerros and Triunfo (Figs 4, 5), in the mesoregions of Agreste and Sertão, respectively (Fig. 6). The physiognomy of the vegetation on both rock outcrops is predominantly shrubby herbaceous with spaced trees, forming clumps of different shapes and sizes separated by bare rock (Figs 1-3, $4,5)$. These areas were selected for sampling, because studies with other plants groups (Silva et al. 2014, Pessoa and Alves 2014) showed high richness and the need to inventory other groups, especially angiosperms.

The Pedra do Cruzeiro $\left(08^{\circ} 09^{\prime} 02.9^{\prime \prime} \mathrm{S}, 035^{\circ} 45^{\prime}\right.$ $22.3^{\prime \prime} \mathrm{W}$ ) is a rock outcrop composed mainly of granite inserted in the Borborema Plateau, surrounded by seasonal decidual forest, ca $150 \mathrm{~km}$ from the coast. It has an average altitude of $760 \mathrm{~m}$, with $2.1 \mathrm{ha}$, in a region of semi-humid tropical climate with a rainy season starting in January and continuing until September, an average annual temperature of $21^{\circ} \mathrm{C}$ and average rainfall of 893 $\mathrm{mm} /$ year (Gomes and Alves 2009, MME 2005).

Pico do Papagaio is the highest point in the state of Pernambuco $\left(07^{\circ} 49^{\prime} 21.9^{\prime \prime} \mathrm{S}, 038^{\circ} 03^{\prime} 19.4^{\prime \prime} \mathrm{W}\right)$, located on the border with Paraíba. It is composed mainly of gra- nitic rock. The maximum altitude is $1200 \mathrm{~m}, 1.1$ ha and it is ca $450 \mathrm{~km}$ from the coast. The climate is hot and humid in the region, with average rainfall of $1222 \mathrm{~mm} /$ year and average annual temperature of $25^{\circ} \mathrm{C}$. It occupies an area surrounded by thorny deciduous forest in the Depressão Sertaneja with characteristic floristic elements of the humid forest because it is a Brejo of Altitude (MME 2005 ) and present higher levels of humidity in relation to the surrounding areas.

Data collection. In order to collect fertile specimens of climbing plants, monthly visits were carried out to both outcrops from February to September 2015, totaling approximately $40 \mathrm{~h}$ of sampling effort for each area. The collection of specimens followed the usual methodology in taxonomy (Mori et al. 1985), wherein samples were photographed, geo-referenced and deposited in the herbarium UFP. In addition, samples that had been previously collected in the study areas, and deposited in the herbaria IPA, PEUFR, HST and UFP, were analyzed.

Taxonomic identification was made through morphological analyses of the reproductive and vegetative characters with the help of a stereo-microscope, consultations of specialized literature (Gentry 1996), field guides or by comparisons with specimens deposited in local herbaria and in online databases.

The list of species was organized in alphabetical order by family, and APG IV (2016) was the classification system adopted. For the spelling of scientific names and authors of the species, as well as information on geographic distribution and endemism, the List of Species of the Flora of Brazil was adopted (BFG 2015). The occurrence of each species in the 3 phyto-geographic domains of the Brazilian Northeast (Caatinga, Cerrado and Atlantic Forest) was also consulted in this database.

The concept of climbers used in this work is that of Weiser (2007). Species were classified according to 
growth form (herbaceous vines and woody vines/lianas) and mechanism or adaptation for climbing (twining, using tendrils or thorns, and scandent) as proposed by Villagra and Romaniuc Neto (2014). The characterization of life form (therophyte, geophyte, hemicryptophyte, chamaephyte and phanerophyte) followed Raunkiaer (adapted from Martins and Batalha 2011). Additionally, some species in the study areas were described.

\section{Results}

In both outcrops 58 species are recorded, belonging to 39 genera and 20 families (Table 1). The most diverse families are Apocynaceae and Convolvulaceae (9 spp.), Fabaceae (7 spp.), and Bignoniaceae and Dioscoreaceae (5 spp.). Together they account for more than $60 \%$ of the species. Alstroemeriaceae, Boraginaceae, Celastraceae, Combretaceae, Menispermaceae, Polygalaceae, Rubiaceae and Smilacaceae together correspond to $40 \%$ of the families identified and are represented by a single species each. Aristolochiaceae, Cucurbitaceae, Euphorbiaceae, Malpighiaceae, Passifloraceae and Vitaceae comprise 2 species each and make up for $30 \%$ of the families catalogued (Table 1). The richest genera are Dioscorea and Ipomoea (5 spp.), and Ditassa (4 spp.).

Of the species recorded, 11 are common to both outcrops and 48 are unique to one area. At Pedra do Cruzeiro 36 species are identified (25 of which are exclusive), belonging to 17 families, the most representative in number of species are Apocynaceae (7 spp.) and Convolvulaceae (5 spp.), the genera Ditassa, Dioscorea, Jacquemontia and Mandevilla (3 spp. each), and Ipomoea (5 spp.). For Pico do Papagaio, 33 species (22 exclusive species) from 15 families were identified, Convolvulaceae and Fabaceae ( $5 \mathrm{spp}$. each) were the richest families, as well as the genus Jacquemontia (3 spp.).

The life form of the areas was predominantly comprised of phanerophytes ( $62 \%$ of the species), followed by geophytes and therophytes (18\% spp. each) and hemicryptophytes ( $2 \%$ spp.). Considering only Pedra do Cruzeiro, $54 \%$ of the species are phanerophytes, followed by geophytes and therophytes ( $8 \%$ each) and hemicryptophytes (2\%). At Pico do Papagaio, 61\% of the species are phanerophytes, followed by therophytes $(21 \%)$ and geophytes (18\%).

About the growth form, $67 \%$ of the species were herbaceous, while the woody form (lianas) was represented by $33 \%$ of the species. A similar proportion was found in each area when considered separately.

Twinings were observed in $69 \%$ of the species, with Apocynaceae, Convolvulaceae, Dioscoreaceae and Fabaceae the families with more species. Among plants with tendrils (28\%), Bignoniaceae and Sapindaceae stand out. Tournefortia membranacea and Emmeorhiza umbellata are both scandent and twining, while Smilax campestris presents tendrils and thorns. Both areas when analyzed separately had twinings and tendril prevailing.

Regarding the phytogeographic domains, 37 species $(62 \%)$ were common to the 3 domains analyzed [Caatinga (CA), Cerrado (CE) and Atlantic Forest (AF)]. Cardiospermum oliverae, Dioclea lasiophylla, Ditassa oxyphylla, Ipomoea subalata, Matelea ganglinosa and Tragia volubilis are distributed in various environments in the CA and AF Domains. Mandevilla microphylla, Combretum hilarianum, Ipomoea brasiliana, Ipomoea subincana, Jacquemontia corymbulosa and Jacquemon-

Table 1. List of climbing plants of 2 rock outcrops in the state of Pernambuco, Brazil. Legend: LOC = locality (PC: Pedra do Cruzeiro, PP: Pico do Papagaio), ADT = adaptation for climbing (th: thorny, sc: scandent, te: tendril, tw: twining), HAB = habit (he: herbaceous, li: woody), DOM = phytogeographic domain occurrence (CA: Caatinga, CE: Cerrado, AF: Atlantic Forest), LF = life-form (ph: phanerophyte, ge: geophyte, he: hemicryptophyte, th: therophyte); specimens analyzed: ExS (D.S. Lucena collection number) and Voucher at UFP-Vch.

\begin{tabular}{|c|c|c|c|c|c|c|c|c|c|}
\hline \multirow{2}{*}{ Species } & \multicolumn{2}{|c|}{ LOC } & \multirow{2}{*}{ ADT } & \multirow{2}{*}{ HAB } & \multicolumn{3}{|c|}{ DOM } & \multirow{2}{*}{ LF } & \multirow{2}{*}{ ExS-Vch } \\
\hline & PC & PP & & & CE & CA & AF & & \\
\hline \multicolumn{10}{|l|}{ Alstroemeriaceae } \\
\hline Bomarea edulis (Tussac) Herb. & $\mathrm{X}$ & $x$ & Tw & he & $x$ & $x$ & $x$ & ge & $708 / 667-81162 / 79361$ \\
\hline \multicolumn{10}{|l|}{ Apocynaceae } \\
\hline Ditassa hispida (Vell.) Fontella. & $x$ & & Tw & he & $x$ & $x$ & $x$ & $\mathrm{ph}$ & $629-79008$ \\
\hline Ditassa obcordata Mart. & $x$ & & Tw & he & $x$ & $x$ & $x$ & $\mathrm{ph}$ & $644-79009$ \\
\hline Ditassa oxyphylla Turcz. & & $x$ & Tw & he & - & $x$ & $x$ & $\mathrm{ph}$ & $680-79367$ \\
\hline Ditassa pohliana E. Fourn. & $x$ & & Tw & he & $x$ & $x$ & $x$ & $\mathrm{ph}$ & $646-79370$ \\
\hline Mandevilla scabra (Hoffmanns. ex Roem. \& Schult) K. Schum. & $x$ & & Tw & he & $x$ & $x$ & $x$ & ge & $522-78950$ \\
\hline Mandevilla tenuifolia (J. C. Mikan) Woodson & $x$ & $x$ & Tw & he & $x$ & $x$ & $x$ & ge & $516 / 702-78946 / 79366$ \\
\hline Mandevilla microphylla (Stadelm.) M. F. Sales \& Kin.-Gouv. & $x$ & & Tw & he & $x$ & $x$ & - & ge & $534-79154$ \\
\hline Matelea ganglinosa (Vell.) Rappini & $\mathrm{X}$ & & Tw & he & - & $x$ & $x$ & $\mathrm{ph}$ & $642-79378$ \\
\hline Schubertia multiflora Mart. & & $x$ & Tw & he & $x$ & $x$ & $x$ & $\mathrm{ph}$ & $663-79368$ \\
\hline \multicolumn{10}{|l|}{ Aristolochiaceae } \\
\hline Aristolochia disticha Mast. & $\mathrm{x}$ & $x$ & Tw & he & $x$ & $x$ & $x$ & $\mathrm{ph}$ & $527 / 657-78945 / 79353$ \\
\hline \multicolumn{10}{|l|}{ Bignoniaceae } \\
\hline Amphilophium paniculatum (L.) Kunth. & & $x$ & $\mathrm{Te}$ & li & $x$ & $x$ & $x$ & $\mathrm{ph}$ & $648-78998$ \\
\hline Dolichandra quadrivalves (Jacq.) L. G. Lohmann. & & $x$ & $\mathrm{Te}$ & li & $\mathrm{x}$ & $x$ & $x$ & $\mathrm{ph}$ & 653-79399 \\
\hline Fridericia triplinervia (Mart. ex DC.) L. G. Lohmam. & & $x$ & $\mathrm{Te}$ & li & $x$ & - & $x$ & $\mathrm{ph}$ & $654-79007$ \\
\hline
\end{tabular}


Table 1. Continued.

\begin{tabular}{|c|c|c|c|c|c|c|c|c|c|}
\hline \multirow{2}{*}{ Species } & \multicolumn{2}{|c|}{ LOC } & \multirow{2}{*}{ ADT } & \multirow{2}{*}{ HAB } & \multicolumn{3}{|c|}{ DOM } & \multirow{2}{*}{ LF } & \multirow{2}{*}{ ExS-Vch } \\
\hline & PC & PP & & & CE & CA & AF & & \\
\hline Mansoa difficilis (Cham.) Bureau \& K. Schum. & $\mathrm{x}$ & & $\mathrm{Te}$ & li & $\mathrm{x}$ & - & $\mathrm{x}$ & $\mathrm{ph}$ & $530-79196$ \\
\hline Pyrostegia venusta (Ker Gawl.) Miers & $\mathrm{x}$ & & $\mathrm{Te}$ & li & $\mathrm{x}$ & $\mathrm{x}$ & $\mathrm{x}$ & $\mathrm{ph}$ & $541-81141$ \\
\hline \multicolumn{10}{|l|}{ Boraginaceae } \\
\hline Tournefortia membranaceae (Gardner) DC. & $x$ & & $\mathrm{Sc} / \mathrm{Tw}$ & li & $x$ & $x$ & $\mathrm{x}$ & $\mathrm{ph}$ & $521-78946$ \\
\hline \multicolumn{10}{|l|}{ Celastraceae } \\
\hline Hippocratea volubilis L. & $x$ & & Tw & li & $\mathrm{x}$ & $x$ & $\mathrm{x}$ & $\mathrm{ph}$ & $514-78947$ \\
\hline \multicolumn{10}{|l|}{ Combretaceae } \\
\hline Combretum hilarianum D. Dietr. & & $x$ & Tw & li & $x$ & $x$ & - & $\mathrm{ph}$ & $686-79350$ \\
\hline \multicolumn{10}{|l|}{ Convolvulaceae } \\
\hline Ipomoea bahiensis Willd. ex Roem. \& Schult. & $\mathrm{x}$ & $\mathrm{x}$ & Tw & he & $\mathrm{x}$ & $\mathrm{x}$ & $\mathrm{x}$ & th & 669/741-79004/78997 \\
\hline Ipomoea brasiliana (Choisy) Meisn. & $x$ & $x$ & Tw & he & $x$ & $x$ & - & $\mathrm{ph}$ & $647 / 684-79347 / 79354$ \\
\hline Ipomoea nil (L.) Roth. & $\mathrm{x}$ & & Tw & he & $x$ & $x$ & $x$ & th & $636-79373$ \\
\hline Ipomoea subalata Hassl. & $\mathrm{x}$ & & Tw & he & - & $\mathrm{x}$ & $\mathrm{x}$ & $\mathrm{ph}$ & $631-79369$ \\
\hline Ipomoea subincana (Choisy) Meisn. & $x$ & & Tw & he & $x$ & $x$ & - & $\mathrm{ph}$ & $510-78591$ \\
\hline Jacquemontia corymbulosa Benth. & & $x$ & Tw & he & $\mathrm{x}$ & $\mathrm{x}$ & - & th & $649-79357$ \\
\hline Jacquemontia ferruginea Choisy. & & $x$ & Tw & he & $x$ & - & $x$ & $\mathrm{ph}$ & $661-79358$ \\
\hline Jacquemontia pentanthos (Jacq.) G. Don. & & $x$ & Tw & he & $x$ & $x$ & - & $\mathrm{ph}$ & $699-79363$ \\
\hline Merremia macrocalyx (Ruiz \& Pav.) O’Donell & $x$ & & Tw & li & $\mathrm{x}$ & $x$ & $x$ & he & $513-78948$ \\
\hline \multicolumn{10}{|l|}{ Cucurbitaceae } \\
\hline Apodanthera glaziovii Cogn. & $x$ & & $\mathrm{Te}$ & he & - & $x$ & - & $\mathrm{ph}$ & $712-81159$ \\
\hline Sicyos polyacanthus Cogn. & & $x$ & $\mathrm{Te}$ & he & $x$ & - & $\mathrm{x}$ & $\mathrm{ph}$ & $654-81153$ \\
\hline \multicolumn{10}{|l|}{ Dioscoreaceae } \\
\hline Dioscorea campestres Griseb. & $x$ & $x$ & Tw & he & $x$ & $x$ & $x$ & ge & $710 / 687-81151 / 79412$ \\
\hline Dioscorea dodecaneura Vell. & $x$ & & Tw & he & $x$ & $x$ & $x$ & ge & $707-81154$ \\
\hline Dioscorea grandiflora Mart. ex Griseb. & $x$ & & Tw & he & $x$ & - & $x$ & ge & $709-81156$ \\
\hline Dioscorea ovata Vell. & & $x$ & Tw & he & $x$ & $x$ & $x$ & ge & $736-79001$ \\
\hline Dioscorea leptostachya Gardner. & & $x$ & Tw & he & $x$ & $x$ & $x$ & ge & $688-78999$ \\
\hline Euphorbiaceae & & & & & & & & & \\
\hline Dalechampia scandens $\mathrm{L}$. & & $x$ & Tw & he & $\mathrm{x}$ & $x$ & $x$ & th & $652-79355$ \\
\hline Tragia volubilis $\mathrm{L}$. & $x$ & & Tw & he & - & $x$ & $\mathrm{x}$ & th & $559-79360$ \\
\hline Fabaceae & & & & & & & & & \\
\hline Canavalia brasiliensis Mart. ex Benth. & & $x$ & Tw & li & $x$ & $x$ & $x$ & $\mathrm{ph}$ & 678-79411 \\
\hline Centrosema brasilianum (L.) Benth. & $x$ & $x$ & Tw & he & $\mathrm{x}$ & $x$ & $\mathrm{x}$ & th & $650 / 720-79410 / 81139$ \\
\hline Chaetocalyx scandens (L.) Urb & & $x$ & Tw & he & $\mathrm{x}$ & $x$ & $x$ & th & $651-79404$ \\
\hline Dioclea grandiflora Mart. ex Benth. & & $x$ & Tw & li & - & $x$ & - & $\mathrm{ph}$ & $672-79354$ \\
\hline Dioclea lasiophylla Mart. ex Benth. & $x$ & & Tw & li & - & $x$ & $\mathrm{x}$ & th & $511-81160$ \\
\hline Leptospron adenanthum (G. Mey.) A. Delgado & $x$ & & Tw & he & $x$ & $x$ & $\mathrm{x}$ & $\mathrm{ph}$ & $713-81155$ \\
\hline Rhynchosia minima (L.) DC. & & $x$ & Tw & li & $x$ & $x$ & $x$ & th & $679-79403$ \\
\hline Malpighiaceae & & & & & & & & & \\
\hline Mascagnia sepium (A. Juss.) Griseb. & $x$ & $x$ & Tw & li & $\mathrm{x}$ & $x$ & $\mathrm{x}$ & $\mathrm{ph}$ & $673-79003$ \\
\hline Tetrapterys mucronata Cav. & $x$ & & Tw & li & $x$ & - & $x$ & $\mathrm{ph}$ & $635-79006$ \\
\hline Menispermaceae & & & & & & & & & \\
\hline Cissampelos glaberrima A. St. Hil. & $\mathrm{x}$ & $x$ & Tw & he & $\mathrm{x}$ & $\mathrm{x}$ & $\mathrm{x}$ & ge & $519 / 676-78952 / 79002$ \\
\hline Passifloraceae & & & & & & & & & \\
\hline Passiflora silvestres Vell. & $x$ & & $\mathrm{Te}$ & he & $x$ & - & $\mathrm{x}$ & $\mathrm{ph}$ & $557-79397$ \\
\hline Passiflora suberosa L. & $x$ & $x$ & $\mathrm{Te}$ & he & $\mathrm{x}$ & $x$ & $x$ & $\mathrm{ph}$ & $528 / 664-78954 / 79365$ \\
\hline Polygalaceae & & & & & & & & & \\
\hline Securidaca diversifolia (L.) S. F. Blake. & $\mathrm{x}$ & & $\mathrm{Te}$ & & $x$ & $x$ & $\mathrm{x}$ & $\mathrm{ph}$ & $537-79161$ \\
\hline Rubiaceae & & & & & & & & & \\
\hline Emmeorhiza umbellata Schum. & $x$ & & $\mathrm{Sc} / \mathrm{Tw}$ & he & $\mathrm{x}$ & $x$ & $\mathrm{x}$ & th & $523-79182$ \\
\hline Sapindaceae & & & & & & & & & \\
\hline Cardiospermum oliverae Ferrucci. & & $x$ & $\mathrm{Te}$ & he & - & $x$ & $x$ & th & $666-79408$ \\
\hline Paullinia pinnata $\mathrm{L}$. & & $x$ & $\mathrm{Te}$ & li & $x$ & $\mathrm{x}$ & $\mathrm{x}$ & $\mathrm{ph}$ & $674-79402$ \\
\hline Serjania marginata Casar. & & $x$ & $\mathrm{Te}$ & he & $x$ & $x$ & $x$ & $\mathrm{ph}$ & $655-78996$ \\
\hline Serjania glabrata Kunth. & $x$ & & $\mathrm{Te}$ & $\mathrm{li}$ & $x$ & $\mathrm{x}$ & $\mathrm{x}$ & $\mathrm{ph}$ & $526-78955$ \\
\hline Smilacaceae & & & & & & & & & \\
\hline Smilax campestres Griseb. & $\mathrm{x}$ & $x$ & $\mathrm{Th} / \mathrm{Te}$ & li & $\mathrm{x}$ & $x$ & $\mathrm{x}$ & $\mathrm{ph}$ & $560 / 681-79396 / 78955$ \\
\hline Vitaceae & & & & & & & & & \\
\hline Clematicissus simsiana (Schult. \& Schult. f.) Lombardi & & $x$ & $\mathrm{Te}$ & he & $x$ & $x$ & $x$ & $\mathrm{ph}$ & 658-79192 \\
\hline Cissus verticillata (L.) Nicolson \& C. E. Jarvis & & $x$ & $\mathrm{Te}$ & he & $x$ & $\mathrm{x}$ & $\mathrm{x}$ & $\mathrm{ph}$ & $682-79180$ \\
\hline
\end{tabular}



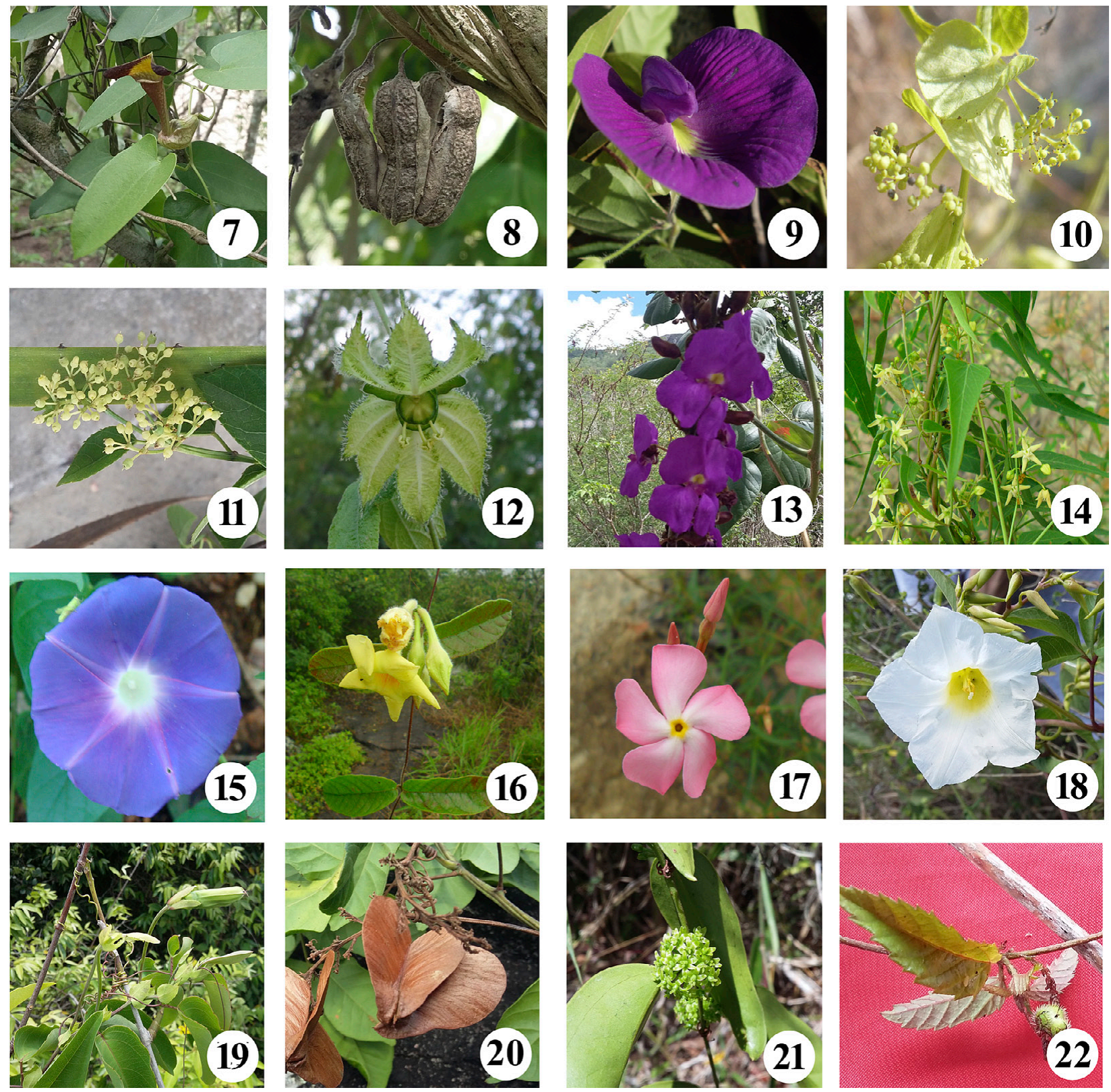

Figures 7-22. Species described in the text. 7, 8. Aristolochia birostris Duchartre. 9. Centrosema brasilianum (L.) Bentham. 10. Cissampelos glaberrima Saint- Hilaire. 11. Cissus verticillata (L.) Nicolson \& Jarvis. 12. Dalechampia scandens Linnaeus (Photo by F. Gomes-Silva). 13. Dioclea grandiflora Martius ex Bentham. 14. Ditassa hastata Decaisne (Photo by T.S. Coutinho). 15. Ipomoea nil (L.) Roth. 16. Mandevilla scabra Schumann (Photo by T.S. Coutinho). 17. Mandevilla tenuifolia (J. C. Mikan) Woodson (Photo by T.S. Coutinho). 18. Merremia macrocalyx (Ruiz \& Pav.) O'Donell. 19. Passiflora silvestres Vellozo. 20. Serjania glabrata Kunth. 21. Smilax campestris Grisebach. 22. Tragia volubilis Linnaeus.

tia pentanthos in the CE and CA. Dioscorea grandiflora, Fridericia triplinervia, Jacquemontia ferruginea, Mansoa difficilis, Passiflora silvestris, Sicyos polyacanthus and Tetrapterys mucronata are found in the CE and AF. Apodanthera glaziovii (Cucurbitaceae) and Dioclea grandiflora (Fabaceae) are exclusive to the CA Domain. Species endemic to rocky outcrops were not identified (Table 1.).

At Pedra do Cruzeiro, 23 species are widely distributed in Brazil and occur in the 3 phytogeographic domains (CA, CE and AF). Only 3 species occur in CA and CE, 4 in $\mathrm{CA}$ and AF, 4 in $\mathrm{CE}$ and AF. Apodanthera glaziovii is the only species endemic to the Caatinga. At Pico do Papagaio 23 species are common to CA, CE and AF, 4 species are common to $\mathrm{CA}$ and $\mathrm{CE}, 3$ in $\mathrm{CA}$ and $\mathrm{AF}$ and 3 to $\mathrm{CE}$ and AF. Dioclea grandiflora was the only 1 endemic to the Caatinga. According to the list of species of the Brazilian flora (BFG 2015), 6 new occurrences were recorded for the state of Pernambuco: Ditassa obcordata, Ditassa pohliana, Mandevilla microphylla (Apocynaceae), Aristolochia disticha (Aristolochiaceae), Dioclea lasiophylla and Leptospron adenanthum (Fabaceae).

\section{Descriptions of some species in the study areas}

Aristolochia birostris Duchartre 1854: 60-62 - Araújo 2013, BFG 2015, Mobot 2016, The Plant List 2016

Material examined. Table 1, Figures 7, 8

Stem voluble, herbaceous, glabrescent when young; 
tendrils absent. Leaf base deeply cordate, apex acute. Perianth strongly zygomorphic, vinaceous to brown. Fruit cylindrical capsule; seed deltoid, warty. It differs from other species by the shape and color of the perianth.

Centrosema brasilianum (L.) Bentham 1837: 54. Silva et al. 2015: 05, Queiroz 2009, BFG 2015, Mobot 2016, The Plant List 2016.

Material examined. Table 1, Figure 9

Stem voluble, herbaceous; tendrils absent. Young stem, petiole, rachis and inflorescence axis glabrous. Leaf 3-foliolate, leaflets glabrescent, ovate to narrow-lanceolate. Flower with purple to violet petals. It differs from other Fabaceae in the study areas mainly by the shape of its leaflets, which in the other species range from deltoid, elliptical, obovate, rhomboid to suborbicular.

Cissampelos glaberrima Saint-Hilaire 1825: 46 Rhodes 1975: 30, Porto and Agra 2013, BFG 2015, Mobot 2016, The Plant List 2016

Material examined. Table 1, Figure 10

Stem voluble, herbaceous, glabrous to glabrescent, striate, tendrils absent. Leaf peltate, heart-shaped. Male and female inflorescences protected by reniform bracts. Fruits red, slightly tubercular. It differs from other species by its peltate leaves and bracts in the inflorescence.

Cissus verticillata (L.) Nicolson \& Jarvis 1984: 33 Lombardi 2013, Heald 2002, BFG 2015, Mobot 2016, The Plant List 2016

Material examined. Table 1, Figure 11

Species highly polymorphic. Stem herbaceous; tendril opposite leaf, which is simple with an entire, denticulate margin. Corolla glabrous, yellowish-green. Differing from Cissus simsiana Schult. \& Schult. f., which has palmately compound leaves.

Dalechampia scandens Linnaeus 1753 - Lucena 2009, BFG 2015, Mobot 2016, The Plant List 2016

Material examined. Table 1, Figure 12

Stem voluble; herbaceous, hirsute; tendril absent. Leaf 3-lobed. Pseudanthium with foliaceous bracts (2) green, 3-lobed. Fruit capsular, compressed-globose; seeds globular. It differs from other Euphorbiaceae in the areas by its lobed bracts and leaves.

Dioclea grandiflora Martius ex Bentham 1837: 68-69Ferreira et al. 2015: 42, Queiroz 2009, BFG 2015, Mobot 2016, The Plant List 2016

Material examined. Table 1; Figure 13.

Stem voluble, woody; tendrils absent. Young stems, petiole, rachis and abaxial surface of leaflets villous. Pod $16 \times 3.5 \mathrm{~cm}$, corroborating Queiroz (2009) and Cordula et al. (2009), with valves woody and villous; seed brown to reddish. It differs from other species of Fabaceae in the study areas mainly by the characteristics of its pods and seeds, as described above.

Ditassa hastata Decaisne 1844 - Konno and Farinaccio 2013, BFG 2015, Mobot 2016, The Plant List 2016
Material examined. Table 1, Figure 14

Stem voluble, herbaceous, glabrous, lactescent; tendril absent. Leaves hastate, sometimes triangular, colleters present at the base. Flowers tiny, white. It differs from other species in the areas by the shape hastate or triangular of its leaves.

Ipomoea nil (L.) Roth (1797) - Buril and Alves 2011, BFG 2015, Mobot 2016, The Plant List 2016

Material examined. Table 1, Figure 15

Stem voluble, herbaceous, hirsute, lactescent, tendril absent. Leaves 3-lobed, base cordate. Corolla funnelshaped, glabrous, lilac, pink to blue with white face. It is different from other species in the areas mainly by the shape 3-lobed of its leaves.

Mandevilla tenuifolia (J. C. Mikan) Woodson 1933 Morales and Simões 2013, BFG 2015, Mobot 2016, The Plant List 2016

Material examined. Table 1, Figure 16

Stem voluble, herbaceous, strigose, vinaceous, lactescent; tendril absent. Leaves linear. Corolla hippocrateriform, floral tube narrow; rosy with whitish face. Differing from other species in the areas by the shape of its perianth and the color of its petals.

Mandevilla scabra Schumann 1895 - Morales and Simões 2013, BFG 2015, Mobot 2016, The Plant List 2016

Material examined. Table 1, Figure 17

Stem voluble herbaceous glabrescent, lactescent; tendril absent. Leaves elliptical, the apex acute and base cordate, colleters along midrib. Corolla hippocrateriform, yellow with a red to orange face. It differs from other species by its colleters along the midrib of the leaf.

Merremia macrocalyx (Ruiz \& Pav.) O’Donell 1941 Buril and Alves 2011, BFG 2015, Mobot 2016, The Plant List 2016

Material examined. Table 1, Figure 18

Stem voluble, herbaceous, glabrous to hirsute, lactescent, tendril absent. Leaves palmately compound, leaflets glabrous. Corolla funnel-shaped, glabrous, white. This species differs from other Convolvulaceae by its divided leaf blade.

Passiflora silvestres Vellozo 1827 - Araújo 2013, BFG 2015, Mobot 2016, The Plant List 2016

Material examined. Table 1, Figure 19

Stem herbaceous, glabrous; tendril axillary. Leaves simple, entire; petiole with stipitate glands (2) at the middle, stipules oval-lanceolate, persistent. Sepals and petals white. It differs from other species by its glands on the petioles and entire leaves.

Serjania glabrata Kunth 1821 - Oliveira 2009, BFG 2015, Mobot 2016, The Plant List 2016

Material examined. Table 1, Figure 20

Stem woody, angular, pubescent to velutinous, lactescent, tendril at the inflorescence base. Leaves 5-foliolate, leaflets with dentate margin, rachis not winged. Flowers 
zygomorphic, white. Fruit schizocarpic with 3 samaroid mericarps. It differs from other species of Sapindaceae in the areas by its fruit type and shape of the foliar rachis.

Smilax campestris Grisebach 1842: 3 - Andreata 1980, BFG 2015, Mobot 2016, The Plant List 2016

Material examined. Table 1, Figure 21

Stem herbaceous, aculeate; tendrils (2) from the sheath apex. Leaf alternate, venation curvilinear. Inflorescence cymose, flowers unisexual, green. It differs from other species by its thorns along the stem.

Tragia volubilis Linnaeus 1753 - Lucena 2009, BFG 2015, Mobot 2016, The Plant List 2016

Material examined. Table 1, Figure 22

Stem voluble, herbaceous, trichomes stinging; tendrils absent. Leaf alternate, margins dentate-serrate. Fruit capsular, tricoccate, compressed-globose; seeds globular. It differs from other species of Euphorbiaceae in the study areas mainly by its glandular, urticating trichomes which are present on the stems and in the inflorescences.

\section{Discussion}

The taxonomic richness seen in this study was greater than that found on other rock outcrops in the Brazilian Northeast, which presented a number of climbing species ranging from five to 27 (França et al. 2005, 2006, Neves and Conceição 2007, Araújo et al. 2008, Porto et al. 2008, Gomes and Alves 2009, Gomes et al. 2011, Tölke et al. 2011, Gomes and Leite 2013, Lucena et al. 2015). It is worth noting that these studies did not have climbing plants as their main focus, a factor that may have influenced the sampling effort and consequently the documented richness of the different areas, in addition to differences in geographic size and preservation status between areas.

Apocynaceae, Bignoniaceae, Convolvulaceae and Fabaceae, were also highlighted in floristic surveys that focused exclusively on the climbing habit in areas of Caatinga (Araújo 2014, Delgado Junior 2014, Oliveira et al. 2015) and Atlantic Forest (Araújo and Alves 2010, Oliveira et al. 2012). According to Gentry (1991), among the vines, these 4 families are the most species-rich in the Neotropics. That author also points out that, while all 3 subfamilies of Fabaceae include climbing species, Papilionoideae presents the largest number of representatives with this habit. In this work, six of the seven species identified in Fabaceae belong to this subfamily.

Considering only the climbers in floristic surveys of rock outcrops in the Northeast, the families Apocynaceae and Convolvulaceae are generally the most species-rich. Araújo (2014) notes that these families have adaptations that facilitate their survival in dry environments, such as anemochoric dispersion and terophyte and geophytic life-form. Also according to that author, anemochory is a determinant character for colonization of climb- ers in the Caatinga and similar vegetation formations, with well-defined seasonality and dominated by trees of small to medium size. Rock outcrop environments are open, dominated by herbaceous and shrubby plant communities with some widely spaced trees, a scenario that facilitates the entry and establishment of diasporas of anemochoric species.

For areas of the Atlantic Forest and Caatinga, Apocynaceae, Bignoniaceae, Convolvulaceae and Fabaceae are also the most representative, alternating their relative position of species richness in the different vegetation types. Convolvulaceae excels in areas of Caatinga, being less representative in areas of Atlantic Forest where Bignoniaceae is more species-rich, while Apocynaceae and Fabaceae are very species-rich in both domains (Zanette 1997, Hora and Soares 2002, Carneiro 2007, Durigon et al. 2009, Villagra and Romaniuc Neto 2009, Udulutsch et al. 2010, Araújo and Alves 2010, Araújo 2014, Delgado Junior 2014).

Despite being among the most species-rich in this work, Dioscoreaceae has been represented by 1 or 2 species in other rock outcrops in the Northeast (Porto et al. 2008, Gomes and Alves 2009, 2010, Gomes et al. 2011, Macedo 2012). The poor representation of this family in the cited studies should be related with the low taxonomic knowledge about the group, specially on species delimitation (Téllez-Valdés and Geeta 2007), which could lead the authors of the aforementioned studies to use a single name for different taxa.

The genus Ipomoea was also the most representative in other studies focusing on climbers (Udulutsch et al. 2004, Durigon et al. 2009, Araújo and Alves 2010, Delgado Jr 2014, Oliveira et al. 2015), is the largest genus of the family Convolvulaceae, with a significant number of climbing species (ca. 600 spp.) and a pantropical distribution, as well as having significant economic importance (Gentry 1991, Bhellum 2012).

Delgado Jr (2014), conducting a floristic survey of climbing plants in an area of Caatinga with limestone rock outcrops in Pernambuco, identified a number of families (18) similar to that found in this study, but with greater species richness (102) of which 25 are common to this study. The families Alstroemeriaceae, Aristolochiaceae, Boraginaceae, Celastraceae, Menispermaceae and Rubiaceae registered for the 2 studied outcrops, were not cataloged by Delgado Jr (2014). This demonstrates the high diversity of climbers in the Caatinga and the uniqueness of rock outcrops. Some species identified here $(M$. tenuifolia, B. edulis, D.oxyphylla, H. volubilis, M. macrocalyx, $C$. verticillata and $C$. simsiana) are common in rock outcrops of the Brazilian northeast (Conceição et al. 2007, Porto et al. 2008, Gomes and Alves 2010, Gomes et al. 2011).

In this study, the low number of species common to both areas may be related to environmental characteristics where the rock outcrops are inserted, the Pedra do Cruzeiro is located in the geoenvironmental unit of the Borborema Plateau and next to the Atlantic coast, surrounded by humid forests, while the Pico do Papagaio is 
a brejo of altitude humid, surrounded by dry forest and with a lower precipitacition index. Environmental characteristics influence the floristic composition of an area (Rodal et al. 2008) and may explain the variation floristic between the 2 outcrops.

A greater richness of herbaceous vines over woody ones was also observed in other studies in the Caatinga Domain (Araújo 2014, Delgado Jr 2014, Oliveira et al. 2015). The phanerophyte life form has been registered as dominant in the floristic inventories of rock outcrops, but in smaller proportions than those registered in this study, despite the higher sampling effort (Conceição et al. 2007, Porto et al. 2008, Gomes and Alves 2010, Macedo 2012, Gomes and Leite 2013). The greater frequency of this life form on the rock outcrops studied could be explained by the presence of cracks and crevices in the rocks, which allow the establishment of tree and shrub species that can support climbers, as well as by the better conservation status of the studied areas, when compared to the studies cited previously.

According to Martinelli (2007), rock outcrops act as floristic refugia for widely distributed species that do not occur in the areas of surrounding vegetation, as observed by Pessoa and Alves (2014) with Orchidaceae. Most species identified in this study (regardless of being exclusive or common among areas) have a wide distribution among the 3 phytogeographic domains of northeastern Brazil (Caatinga, Cerrado and Atlantic Forest) but grow in areas of rock outcrops and the surrounding vegetation. This condition differs partially from that described by Martinelli (2007). Suggesting that the distribution pattern of climbers for rock outcrops are less restricted by the surrounding conditions than other botanical groups.

The twining adaptation for climbing, most common among species of the areas studied here, corroborates the results observed in other studies with climbing plants in Brazil (Appolinário 2008, Barros et al. 2009, Araújo 2014, Delgado Jr 2014, Oliveira et al. 2015). Araújo (2014), in turn, suggests that these adaptations are not related to vegetation types, but to competitiveness, as twining favors rapid growth of the stem.

Despite the low incidence of endemic representatives, the studied rock outcrops have a high richness of climbers, compared with other rock outcrops of the semiarid region of Brazil, and therefore represent important areas for conservation of diversity.

\section{Acknowledgements}

The authors thank T.S. Coutinho (Apocynaceae), M.C. Medeiros (Bignoniaceae), E. Córdula and R. Castro (Fabaceae) for their help with the identifications, and members of the MTV lab (UFPE) in the collection, herborization and cataloging of the botanical material. The authors also thank the curator, M.C.A. Barbosa, and the staff of UFP herbarium, Capes for the master's grant to the first author and Scott Heald for the translation of this manuscript into English.

\section{Authors' contributions}

DSL and MVSA collected the specimens, analyzed the data and drafted the manuscript, MFAL revised and edited the text.

\section{References}

Ab'Sáber AN (2003) Os domínios da Natureza no Brasil: Potencialidades Paisagísticas. Ateliê Editorial, São Paulo, 160 pp.

Andreata RHP (1980) Smilax Linnaeus (Smilacaceae) ensaio para uma revisão das espécies brasileiras. Arquivos do Jardim botânico do Rio de Janeiro 24: 179-301.

Angiosperm Phylogeny Group (2016) An update of the Angiosperm Phylogeny Group classification for the orders and families of flowering plants: APG IV. Botanical Journal of the Linnean Society 181: 1-20. https://doi.org/10.1111/boj.12385

Appolinário V (2008) Taxocenose de Trepadeiras em Fragmentos e Corredores Florestais de Lavras (MG): Aspectos Estruturais e Ecológicos. PhD thesis, Universidade Federal de Lavras, Lavras, 75 pp. http://repositorio.ufla.br/jspui/bitstream/1/3764/1/TESE_ Taxocenose $\% 20$ de $\% 20$ trepadeiras $\% 20 \mathrm{em} \% 20$ fragmentos $\% 20$ e\%20corredores\%20florestais\%20de\%20Lavras-MG.pdf

Araújo FS, Oliveira RF, Lima-Verde LW (2008) Composição, espectro biológico e síndromes de dispersão da Vegetação de um inselbergue no domínio da caatinga, Ceará. Rodriguésia 59 (4): 659-671.

Araújo, D and Alves M (2010) Climbing plants of fragmented area of lowland Atlantic Forest, Igarassu, Pernambuco (northeastern Brazil). Phytotaxa 8 (1): 1-24. http://doi.org/ccmq

Araújo AAM (2013) Aristolochiaceae. In: Flora de Sergipe. Prata APN, Amaral MCE, Farias, Alves MV (Eds) Flora de Sergipe. Gráfica e Editora Triunfo, Aracajú, 96-100.

Araújo, D (2014) Trepadeiras do Bioma Caatinga. In: Villagra BLP, Melo MMRF, Romaniuc Neto S, Barbosa LM (Eds) Diversidade e Conservação de Trepadeiras Contribuição para Restauração de Ecossistemas Brasileiros. Instituto de botânica, São Paulo, 33-58.

Barros AAM, Ribas LA, Araujo DSD (2009) Trepadeiras do Parque Estadual da Serra da Tiririca, Rio de Janeiro, Brasil. Rodriguésia 60 (3): 681-694.

Bentham, G (1837) Commentationes de Leguminosarum Generibus. J.P. Sollingeri, Vindobonae, $80 \mathrm{pp}$.

BFG (2015) Growing knowledge: an overview of seed plant diversity in Brazil. Rodriguésia 66 (4): 1085-1113. http://doi.org/ccmr

Brandes AFN (2007) Anatomia do lenho e dendrocronologia de lianas da família leguminosae ocorrentes na mata atlântica. MSc dissertation. Instituto de Pesquisas Jardim Botânico do Rio de Janeiro, Rio de Janeiro, 104 pp. http://vm005.jbrj.gov.br/enbt/posgraduacao/ resumos/2007/diss_arno_def.pdf

Bhellum BL (2012) Taxonomic studies on genus Ipomoea (Convolvulaceae) in the flora of Jammu and Kashmir state. Journal of Plant Biology Research 1 (1): 29-35.

Buril MT, Alves M (2011) Flora da Usina São José, Igarassu, Pernambuco: Convolvulaceae. Rodriguésia 62 (1): 093-105. https://doi. org/10.1590/2175-7860201162107

Cain SA (1950) Life forms and phytoclimate. Botanical Review 16 (1): $1-32$.

Carneiro JS (2007) Trepadeiras em fragmentos de floresta estacional semidecidual-Paraná, Brasil. MSc dissertation, Universidade Estadual de Londrina, Londrina, 54 pp. http://www.bibliotecadigital.uel.br/document/?code $=$ vtls000146682

Conceição AA, Pirani JR, Meirelles ST (2007) Floristics, structure and soil of insular vegetation in fourquartzite-sandstone outcrops of "Chapada Diamantina", northeast Brazil. Brazilian Journal of Botany 30: 641-656. http://doi.org/dtb4p7

Cordula E, Queiroz LP, Alves M (2009) Leguminosae. In: Alves M, Araújo MFAL, Maciel JR, Martins S (Eds) Flora de Mirandiba. Associação plantas do Nordeste, Recife, 183-233. 
Darwin C (1867) On the movements and habits of climbing plants. Botanical Journal of the Linnean Society 9 (1): 1-118.

Decaisne J (1844) Prodromus Systematis Naturalis Regni Vegetabilis ... Sumptibus Sociorum Treuttel et Würtz, Parisii, 575 pp.

Delgado Jr GC (2014) Flora das Plantas Trepadeiras do Parque Nacional do Catimbau, Pernambuco, Brasil. MSc dissertation, Universidade Federal de Pernambuco, Recife, 198 pp.

Duchartre PES (1854) Annales des Sciences Naturelles. Botanique 2: 60-62.

Durigon J, Canto-Dorowand TS, Eisinger SM (2009) Composição Florística de Trepadeiras ocorrentes em bordas de fragmentos de floresta estacional, Santa Maria, Rio Grande do Sul, Brasil Rodriguésia 60 (2): 415-422.

Fabricante JR, Andrade LA, Marques JM (2010) Caracterização populacional de Melocactus zehntneri (Britton \& Rose) Luetzelburg (Cactaceae) ocorrente em um Inselbergue da Caatinga paraibana. Revista Biotemas 23 (1): 61-67. http://doi.org/dc3pq8

Ferreira PSM, Trovão DMBM, Melo JIM (2015) Leguminosae na APA do Cariri, Estado da Paraíba, Brasil. Hoehnea 42 (3): 531-547. https://doi.org/10.1590/2236-8906-04/2015

França F, Melo E, Santos AKA, MELO JGAN, Marques M, Silva Filho MFB, Moraes L, Machado C (2005) Estudos ecológico e florístico em ilhas de vegetação de um Inselberg no semi-árido da Bahia, Brasil. Hoehnea 32 (1): 93-101.

França F, Melo E, Gonçalves JM (2006) Aspectos da diversidade da vegetação no topo de um inselbergue no semi-árido da Bahia, Brasil. Sitientibus 6 (1): 30-35.

Fordjour PA, Anning AK, Atakora EA, Agyei PS (2008) Diversity and distribution of climbing plants in a semi-deciduous rain forest, KNUST Botanic Garden, Ghana. International Journal of Botany 4 (2): 172-175.

García-Gonzalez JD (2011) Diversidade e abundância de lianas em uma área de Floresta Atlântica Semidecidual ao norte do estado de Pernambuco. MSc dissertation, Universidade Federal de Pernambuco, Recife, 102 pp.

Gentry, AG (1991) The distribution and evolution of climbing plants In: Putz FE, Mooney HA (Eds) The Biology of Vines. Cambridge University Press, Cambridge, 3-39.

Gentry AH (1996) A Field Guide to the Families and Genera of Woody Plants of Northwest South America (Colombia, Ecuador, Peru). University of Chicago, Chicago, $895 \mathrm{pp}$.

Gomes P, Alves M (2009) Floristic and vegetational aspects of an inselberg in the semi-arid region of northeast Brazil. Edinburgh Journal of Botany 66 (2): 1-18. http://doi.org/d9h5nv

Gomes P, Alves M (2010) Floristic diversity of two crystalline rocky outcrops in the Brazilian northeast semi-arid region. Revista Brasileira de Botânica 33 (4): 661-676. http://doi.org/bzhvr2

Gomes P, Costa KCC, Rodal MJN, Alves M (2011) Checklist of angiosperms from the Pedra Furada Municipal Park, northeastern Brazil. Check List 7 (2): 173-181. https://doi.org/10.15560/7.2.173

Gomes P, Leite MS (2013) Crystalline rock outcrops in the Atlantic Forest of northeastern Brazil: vascular flora, biological spectrum, and invasive species. Brazilian Journal of Botany 36 (2): 111-123. https://doi.org/10.1007/s40415-013-0020-7

Grisebach AHR (1842) Smilacaceae. In: Martius CFPV, Eichler AG (Eds) Flora Brasiliensis. Enumeratio Plantarum, Brasília, 1-24.

Heald SV (2002) Vitaceae. In: Mori SA, Cremers G, Gracie CA, Granville JJ, Heald SV, Hoff M, Mitchell JD (Eds) Guide to the Vascular Plants of Central French Guiana, Part. 2. New York Botanical Garden, New York, 740-742.

Hora RC and Soares JJ (2002) Estrutura fitossociológica da comunidade de lianas em uma floresta estacional semidecidual na Fazenda Canchim, São Carlos, SP. Revista Brasileira de Botânica 25 (3): 323-329.

Hora RC, Primavesi O, Soares JJ (2008) Contribuição das folhas de lianas na produção de serapilheira em um fragmento de floresta estacional semidecidual em São Carlos, SP. Revista Brasileira de Botânica 31 (2): 277-285.
Jatobá L, Lins RC (2003) Introdução à Geomorfologia. Bagaço, Recife, $166 \mathrm{pp}$.

Konno TUP, Farinaccio MA (2013) Ditassa (Apocynaceae). In: MCE MCVMV Eds Flora de Sergipe. Gráfica e Editora Triunfo, Aracajú, $57-62$.

Kunth KS (1821) Nova Genera et Species Plantarum ..., 6. Sumtibus Librariae Graeco-Latino-Germanico, Lutetiae Parisiorum, 110 pp. https://doi.org/10.5962/bhl.title.640

Linnaeus C (1753) Species Plantarum. Laurentii Salvii, Estocolmo, $1200 \mathrm{pp}$.

Lombardi J (2013) Vitaceae. In: Prata APN, Amaral MCE, Farias MCV, Alves MV (Eds) Flora de Sergipe. Gráfica e Editora Triunfo, Aracajú, 556-565.

Lucena MFA (2009) Diversidade de Euphorbiaceae (s.1.) no Nordeste do Brasil. PhD thesis, Universidade Federal de Pernambuco, Recife, 194 pp. http://repositorio.ufpe.br/bitstream/handle/123456789/722/ arquivo7077_1.pdf

Lucena DS, Lucena MFA, Sousa JM, Silva RFL, Souza PF (2015) Flora vascular de um inselbergue na mesorregião do sertão paraibano, nordeste do Brasil. Scientia Plena 11 (1): 1-11.

Macedo KM (2012) Florística e espectro Biológico de Afloramentos rochosos graníticos em um trecho do semiárido brasileiro. MSc dissertation, Universidade Federal de Pernambuco, Recife, 59 pp.

Martinelli G (2007) Mountain biodiversity in Brazil. Revista Brasileira de Botânica 30 (4): 587-597.

Martins FR, Batalha MA (2011) In: Felfili JM, Eisenlohr PV, Melo MMRF, Andrade LA, Meira Neto JAA (Eds) Fitossociologia no Brasil: Métodos e Estudos de Casos. Editora UFV, Viçosa, 44-86.

Martius CFPV (1837) Commentationes de Leguminosarum Generibus. Societate Linneana Londinensi, Londres, $380 \mathrm{pp}$.

MME (Ministério de Minas e Energia) (2005) Diagnóstico do Município de Bezerros. http:/www.cprm.gov.br/rehi/atlas/paraiba/relatorios/ PAUL132.pdf. Accessed on: 2015-12-1.

Mobot (Missouri Botanical Garden) (2016) http://www.tropicos.org/ Accessed on: 2016-4-1.

Morales JF, Simões AO (2013) Mandevilla (Apocynaceae). In: Prata APN, Amaral MCE, Farias MCV, Alves MV (Eds) Flora de Sergipe. Gráfica e Editora Triunfo, Aracajú, 68-71.

Mori SA, Silva LAM, Lisboa G, Coradin L (1985) Manual de Manejo do Herbário Fanerogâmico. Centro de Pesquisas do Cacau, Ilhéus, 97 pp.

Morais MVR (1983) O estudo dos inselbergues. Revista de Ensino de Geografia 1 (4): 69-81.

Neves SPS, Conceição AA (2007) Vegetação em afloramentos rochosos na serra do sincorá, Chapada Diamantina, Bahia, Brasil. Sitientibus 7 (1): 36-45.

Nicolson DH, Jarvis CE (1984) Cissus verticillata, a new combination for C. sicyoides (Vitaceae). Taxon 33 (4): 726-727. https://doi. org/10.2307/1220796

O’Donell CA (1941) Merremia macrocalyx (Ruiz \& Pav.) O’Donell. Lilloa 6 (2): 506-511.

Oliveira MA (2009) Sapindaceae. In: Prata APN, Amaral MCE, Farias MCV, Alves MV (Eds) Flora de Sergipe. Gráfica e Editora Triunfo, Aracajú, 332-334.

Oliveira ACP, Mota LM, Loiola MIB (2012) Diversidade florística e chave de identificação de trepadeiras em uma floresta estacional semidecidual em Parnamirim-RN, Brasil. Revista Caatinga 25 (2): $153-158$.

Oliveira DG, Matos GMA, Prata APN (2015) Diversidade florística e estratégias de sobrevivência em um fragmento de Caatinga em porto da folha Sergipe, Brasil. Biotemas 28 (2): 51-60. http://doi.org/ccgg

Pessoa E, Alves M (2014) Orchidaceae em afloramentos rochosos do estado de Pernambuco, Brasil. Rodriguésia 65 (3): 717-734. https://doi.org/10.1590/2175-7860201465311

Porembski S (2007) Tropical inselbergs: habitat types, adaptive strategies and diversity patterns. Revista Brasileira de Botânica 30 (4): 579-586.

Porto PAF, Almeida A, Pessoa WJ, Trovão D, Felix LP (2008) 
Composição florística de um inselbergue no agreste paraibano, município de Esperança, nordeste do Brasil. Revista Caatinga 21 (2): 214-223

Porto NM, Agra MF (2013) Menispermaceae. In: Prata APN, Amaral MCE, Farias MCV, Alves MV (Eds) Flora de Sergipe. Gráfica e Editora Triunfo, Aracajú, 353-360.

Putz FE (1984) The natural history of lianas on Barro Colorado Island, Panama. Journal of Ecology 16 (6): 1713-1724.

Queiroz LP (2009) Leguminosas da Caatinga. Universidade Estadual de Feira de Santana, Feira de Santana, 467 pp.

Rhodes DG (1975) A revision of the genus Cissampelos. Phytologia 30 (6): 415-484.

Rodal MJN, Barbosa MRV, Thomas WW (2008) Do the seasonal forests in northeastern Brazil represent a single floristic unit? Brazilian Journal of Biology 68 (3): 631-637. http://doi.org/ft94n2

Rodrigues JS, Brasileiro JCB, Melo JIM (2014) Flora de um Inselberg na mesorregião agreste do estado da Paraíba-Brasil. Revista Polibotanica 37 (1): 47-61.

Roth AW (1797) Catalecta Botanica: quibus plantae novae et minus cognitae descriuntur atque illustratur. Fasc. 1. I.G. Müller, Lipsiae, 244 pp. https://doi.org/10.5962/bhl.title.124909

Safford HD, Martinelli G (2000) Southeast Brazil. In: Porembski S, Barthlott W (Eds) Inselbergs: Biotic Diversity of Isolated Rock Outcrops in Tropical and Temperate Regions. Springer, Berlin, 339-389.

Saint-Hilaire, AFCP (1825) Flora Brasiliae Meridionales. Tomus 1. A. Belin, Paris, 395 pp., 82 pl. https://doi.org/10.5962/bhl.title.45474

Schumann KM (1895) Die Natürlichen Pflanzenfamilien 4 (2): 171.

Silva JWS, Dantas IC, Chaves TP, Felismino DC (2010) Estudo florístico do sítio arqueológico Pedra-do-Touro no Município de Queimadas, PB. Revista Biofar 4 (2): 47-57.

Silva TO, Silva MPP, Porto KC (2014) Briófitas de Afloramentos Rochosos do Estado de Pernambuco, Brasil. Boletim do Museu de Biologia Mello Leitao 36 (1): 85-100.

Silva MF, Carmo MNL, Gurgel ESC (2015) Phaseoleae (LeguminosaePapilionoideae) nas restingas do Estado do Pará, Brasil. Biota Amazônia 5 (3): 14-22. http://doi.org/cbr9

Téllez-Valdés O, Geeta R (2007) Sinopsis taxonómica de la sección Apodostemon (Dioscorea; Dioscoreaceae). Revista Mexicana de
Biodiversidad 78 (2): 265-279.

The Plant List (2016) http://www.theplantlist.org/. Accessed on: 20164-1.

Thiers B (2015) Index herbariorum: a global directory of public herbaria and associated staff. The New York Botanical Garden. http:// sciweb.nybg.org/science2/IndexHerbariorum.asp. Accessed on: 2015-1-1.

Tölke, EEAD, Silva JB, Pereira ARL,Melo JIM (2011) Flora vascular de um inselbergue no estado da Paraíba, nordeste do Brasil. Revista Biotemas 24 (4): 39-48. http://doi.org/fb8srf

Udulutsch RG, Assis MA, Picchi DG (2004) Florística de trepadeiras numa floresta estacional semidecídua, Rio Claro/Araras, Estado de São Paulo, Brasil. Revista de Botânica 27 (1): 125-134. http://doi. org/devzx 9

Udulutsch RG, Souza VC, Rodrigues RR, Dias P (2010) Composição florística e chaves de identificação para lianas da Estação Ecológica dos Caeteus, Estado de São Paulo, Brasil. Rodriguésia 61 (4): 715-730.

Vargas BC, Araújo GM, Schiavini I, Rosa PO, Hattori EKO (2013) Florística de trepadeiras em floresta semidecidual e em mata ciliar no vale do rio Araguari, MG. Bioscience Journal 29 (1): 185-197.

Vellozo JMC (1827) Florae Fluminensis, Descriptionum plantarum parectura Fluminensi sponte mascentium liber primus ad systema sexuale concinnatus. Typographia Nationali, Rio de Janeiro, 352 pp.

Villagra BLP, Romaniuc-Neto S (2010) Florística de trepadeiras no Parque Estadual das Fontes do Ipiranga, São Paulo, SP, Brasil. Revista Brasileira de Biociências 8 (2): 186-200.

Weiser VL, Godoy SAP (2001) Florística de um hectare de cerrado strict sensu na ARIE - Cerrado Pé-de-Gigante, Santa Rita do Passo Quatro, SP. Acta Botanica Brasilica 15 (2): 201-212.

Weiser VL (2007) Árvores, Arbustos e trepadeiras do cerradão do Jardim botânico municipal de Bauru. PhD thesis, Universidade Estadual de Campinas, Campinas, 111 pp. http://repositorio.unicamp.br/jspui/ bitstream/REPOSIP/315873/1/Weiser_VeridianadeLara_D.pdf

Woodson RE (1933). Studies in the Apocynaceae IV. Annals of the Missouri Botanical Garden 20 (4): 605-790.

Zanette VC, Soares JJ, Martinello CM (1997) Lianas de um remanescente florestal da microbacia do rio novo, Orleans, Santa Catarina, Brasil. Insula 26: 45-63. 